\title{
PLACENTUM
}

\section{PENGARUH VIGNA RADIATA TERHADAP ANEMIA}

\section{The Effect of Vigna Radiata on Anemia}

\author{
Erindra Budi C, Dian Yudita, Sri Mulyani, Mujahidatul M, Ika Sumiyarsi S \\ Program Studi Kebidanan Program Sarjana Terapan FK UNS \\ email:erindrabudi2007@yahoo.com
}

\begin{abstract}
ABSTRAK
Latar Belakang: Anemia defisiensi besi merupakan masalah yang paling banyak dialami wanita yang tidak mempunyai asupan dan cadangan zat besi yang cukup. Salah satu sumber makanan yang mengandung zat besi adalah kacang hijau (Vigna Radiata) yang mengandung sekitar $6.7 \mathrm{mg}$ zat besi per 100 gram serta zat nutrisi lainnya yang dapat meningkatkan kadar hemoglobin sebagai parameter status anemia. Penelitian ini bertujuan untuk mengetahui hubungan antara konsumsi jus Vigna radiata dan status anemia.

Metode: Rancangan penelitian one group pre test post test design. Teknik sampling yang digunakan adalah simple random sampling dengan jumlah sampel 16 subjek mahasiswi Prodi D III Kebidanan STIKES Aisyiyah Surakarta. Intervensi dengan pemberian jus kacang hijau $500 \mathrm{~mL}$ selama tujuh hari. Pengukuran hemoglobin pre dan post intervensi di Puskesmas Ngoresan Surakarta.Teknik analisis data dengan uji McNemar.

Hasil: Sebelum dilakukan intervensi, subjek dengan anenia sebanyak 12 orang, tidak anemia empat orang. Setelah intervensi, subjek dengan anemia sebanyak delapan orang, tidak anemia delapan orang. Uji beda Mc Nemar dengan taraf signifikansi 0.05 diperoleh nilai signifikansi (p) 0.03 .
\end{abstract}

Kesimpulan: Ada hubungan yang bermakna antara konsumsi jus Vigna radiata dan kadar anemia.

Kata Kunci: Jus Vigna Radiata, Anemia. 


\section{ABSTRACT}

Background: Iron deficiency anemia is a problem most experienced by women who do not have adequate iron intake and reserves. One food source that contains iron is green beans (Vigna Radiata) which contains about $6.7 \mathrm{mg}$ of iron per 100 grams and other nutrients that can increase hemoglobin levels as a parameter of anemia status. This study aims to determine the relationship between Vigna radiata juice consumption and anemia status.

Method: One group pre-test post-test design research design. The sampling technique used was simple random sampling with a sample size of 16 female students of D III Midwifery Study Program Aisyiyah Surakarta. Intervention with administration of $500 \mathrm{~mL}$ green bean juice for seven days. Pre and post intervention hemoglobin measurements at the Surakarta Ngoresan Health Center. Data analysis technique was by using McNemar test.

Results: Before the intervention, there were 12 subjects with anemia, not four people with anemia. After the intervention, there were eight subjects with anemia, eight without anemia. Mc Nemar different test with a significance level of 0.05 obtained a significance value (p) 0.03 .

Conclusion: There is a significant relationship between consumption of Vigna radiata juice and anemia levels.

Keywords: Vigna Radiata Juice, Anemia.

\section{LATAR BELAKANG}

Anemia merupakan masalah kesehatan masyarakat terbesar di dunia yang dijadikan salah satu indikator masalah kesehatan dan gizi buruk. Anemia yang paling banyak terjadi di dunia adalah anemia defisiensi besi yang dialami lebih dari 600 juta manusia dan masih menjadi masalah utama di pelayanan kesehatan, khusunya pada wanita dan anak ${ }^{1]}$. WHO menyebutkan bahwa anemia defisiensi besi merupakan salah satu faktor yang dapat meningkatkan angka kematian di negara berkembang dan menjadi penyebab kedua morbiditas dan mortalitas yang membunuh satu juta manusia setiap tahunnya ${ }^{[1]}$.

Prevalensi anemia di dunia terjadi pada wanita yang tidak hamil cukup tinggi yaitu sekitar 35\%. Proporsi anemia di Indonesia menurut kelompok usia 1524 tahun sebesar 18,4\% dan lebih banyak dialami oleh wanita dengan proporsi sebesar 23,9\%. Wanita mengalami kehilangan darah secara alamiah setiap bulannya melalui proses menstruasi. Jika darah yang dikeluarkan terlalu banyak,
\end{abstract}

maka akan meningkatkan risiko terjadinya anemia defisiensi zat besi ${ }^{[2][3]}$.

Anemia ditandai dengan rendahnya konsentrasi hemoglobin atau hematokrit dibawah nilai ambang batas yang disebabkan oleh rendahnya produksi sel darah merah dan anemia, meningkatnya kerusakan eritrosit, atau kehilangan darah yang berlebih. Anemia defisiensi besi disebabkan oleh kekurangan zat besi dalam jumlah yang tidak mencukupi kebutuhan sehari-hari ${ }^{[4][5]}$. Zat besi berperan dalam pengaturan molekul anemia sel-sel darah merah. Anemia bertanggung jawab dalam pendistribusian oksigen dari paru-paru ke seluruh jaringan tubuh. Zat besi juga berperan dalam metabolisme energi, termasuk sintesis DNA oleh beberapa enzim, serta berperan dalam sistem kekebalan tubuh ${ }^{[6]}$.

Pencegahan dan pengobatan anemia salah satunya dapat dilakukan dengan meningkatkan asupan zat besi melalui makanan. Faktor lainnya yang dapat mempengaruhi penyerapan zat besi di dalam tubuh adalah kebiasaan mengonsumsi kopi, teh, makanan/ 
minuman yang mengandung magnesium maupun kalsium secara bersamaan dengan zat besi ${ }^{[7][8]}$. Salah satu sumber tambahan makanan yang mengandung zat besi non-heme adalah Vigna Radiata. Vigna Radiata atau dengan nama latin Vigna Radiata L. mempunyai kandungan zat besi sebesar $6.7 \mathrm{mg}$ per 100 gram $^{[9]}$. Vigna Radiata merupakan makanan yang dianjurkan untuk dikonsumsi karena mempunyai kandungan zat gizi yang baik untuk membantu pembentukan sel-sel tubuh. Vigna Radiata juga bermanfaat untuk memperlancar saluran pencernaan dan mencegah konstipasi, berperan dalam pembentukan sel darah merah dan mencegah anemia, serta berperan dalam menjaga kesehatan tulang dan gigi ${ }^{[6][10]}$.

\section{SUBJEK DAN METODE \\ Rancangan penelitian one group pre test post test design. Populasi adalah mahasiswi Prodi D III Kebidanan STIKES Aisyiyah Surakarta. Teknik sampling menggunakan simple random sampling dengan jumlah sampel 16 subjek yang telah mendapat penjelasan dan bersedia menjadi subjek penelitian. \\ Kriteria inklusi dalam penelitian ini meliputi: menjalani intervensi secara lengkap dan bersedia diperiksa darahnya. Sedangkan kriteria eksklusi dalam penelitian ini adalah subjek sedang hamil; menstruasi; mengonsumsi suplemen/ vitamin; serta mengonsumsi teh/ kopi 2 jam sebelum dan sesudah intervensi. Intervensi dengan pemberian jus kacang hijau $500 \mathrm{~mL}$ selama tujuh hari. Pengukuran hemoglobin pre dan post intervensi di Puskesmas Ngoresan Surakarta. Teknik analisis data dengan Uji McNemar.}

\section{HASIL}

\section{Analisis Univariat}

Tabel 1. Status Anemia Sebelum Intervensi

\begin{tabular}{cc}
\hline Status Anemia & Jumlah \\
\hline Anemia & 12
\end{tabular}

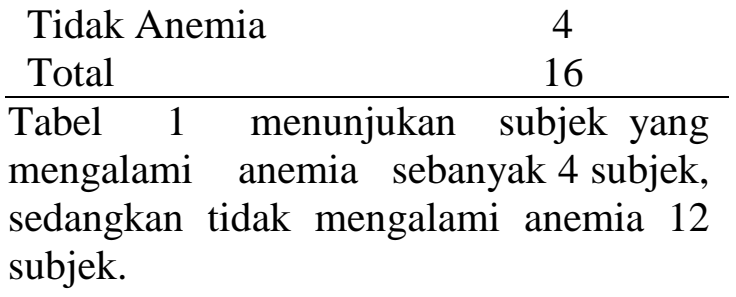

Tabel 2. Status Anemia Setelah Intervensi

\begin{tabular}{|c|c|}
\hline Status Anemia & Jumlah \\
\hline Anemia & 8 \\
\hline Tidak Anemia & 8 \\
\hline Total & 16 \\
\hline
\end{tabular}

Analisis Bivariat

Tabel 3. Hasil Uji Beda

\begin{tabular}{lc}
\hline \multicolumn{1}{c}{ Variabel } & $\mathrm{p}$ \\
\hline Anemia & 0.031 \\
Tidak Anemia & \\
\hline
\end{tabular}

Tabel 3 menunjukan bahwa dari hasil uji statistik dengan uji Mc Nemar diperoleh nilai sig $(p)<0.05$. Hal ini berarti terdapat perbedaan yang signifikan antara status anemia subjek sebelum dan setelah intervensi. Dapat disimpulkan bahwa ada hubungan antara konsumsi jus Vigna radiata dan status anemia.

\section{PEMBAHASAN}

Salah satu penyebab anemia adalah rendahnya asupan zat besi. Rendahnya asupan zat besi dapat menurunkan produksi sel darah merah sehingga sintesis anemia juga akan menurun yang menyebabkan seseorang berisiko mengalami anemia ${ }^{[11]}$. Kebutuhan zat besi pada seorang perempuan dua kali lebih besar dibandingkan dengan laki-laki, sehingga jika kebutuhan tersebut tidak tercukupi akan dapat meningkatkan terjadinya anemia pada perempuan. Aktivitas juga menjadi salah satu faktor yang mempengaruhi kebutuhan zat besi di dalam tubuh. Kebutuhan zat besi seseorang ditentukan oleh aktivitas yang dilakukan setiap harinya. Semakin berat aktivitas yang dilakukan, maka akan semakin tinggi 
kebutuhan zat besi tersebut. Hal ini dikarenakan beratnya aktivitas yang dilakukan akan membuat kebutuhan tubuh terhadap oksigen meningkat ${ }^{[12]}$. Perempuan yang mengalami masalah anemia harus segera ditangani karena dapat menurunkan daya tahan tubuh, produktivitas kerja, kemampuan dan konsentrasi belajar, kemampuan mengatur suhu tubuh, kebugaran tubuh, pertumbuhan, serta mengakibatkan muka terlihat pucat ${ }^{[14]}$. Kondisi ini juga dirasakan subjek yang mengalami anemia. Subjek merasa saat perkuliahan konsentrasi belajar menjadi menurun karena lemas dan mengantuk, selain itu mereka menjadi mudah sakit. Perempuan yang mengalami anemia perlu diperbaiki status zat besinya, sehingga diharapkan dapat meningkatkan prestasi akademik maupun produktivitas kerjanya $^{[15]}$.

Hasil wawancara pada subjek yang mengalami anemia (kadar Hemoglobin $<12 \mathrm{~g} / \mathrm{dl}$ ) menyatakan bahwa selama ini mereka sering mengalami keluhan seperti: cepat merasa lemas, letih, pusing, serta nafsu makan berkurang. Hal ini sesuai dengan ${ }^{13]}$ yang menyebutkan bahwa tanda gejala anemia yang dapat dilihat adalah wajah terlihat pucat; kelopak mata, bibir, lidah, kulit, dan telapak tangan pucat; terlihat gelisah; irama jantung cepat; serta nafsu makan berkurang. Gejala umum lainnya adalah lemah, letih, lesu, lelah, dan lalai; mata berkunang-kunang; sesak napas; telinga mendenging (tinnitus); serta kaki teraba dingin.

Pemberian Jus Vigna Radiata memberi pengaruh yang bermakna terhadap kadar anemia. Hasil ini sesuai dengan penelitian ${ }^{[16]}$ yang menunjukan bahwa ada pengaruh positif minuman kacang hijau terhadap kadar anemia pada pendonor darah di UDD PMI Cabang Kabupaten Pekalongan. Hasil penelitian ini juga sesuai dengan penelitian ${ }^{[17]}$ yang menunjukan bahwa ada hubungan yang bermakna antara jus Vigna Radiata dengan kadar anemia pada pasien kanker yang menjalanikemoterapi. Penelitian yang telah dilakukan $^{[18]}$ juga menyebutkan bahwa pemberian makanan yang kaya zat gizi (terutama zat besi) dapat meningkatkan kadar anemia dan serum zat besi sehingga dapat menurunkan risiko terjadinya anemia defisiensi besi yang banyak dialami oleh wanita.

Masalah anemia pada perempuan dapat diatasi dengan mengonsumsi makanan yang mengandung zat besi. Vigna radiata merupakan salah satu sumber makanan tambahan yang mengandung zat besi non-heme $(6.7 \mathrm{mg}$ per 100 gram Vigna radiata). Vigna radiata juga dikenal sebagai protein nabati karena kandungan proteinnya cukup tinggi yaitu sekitar 22.2 gram per 100 gram. Selain itu kandungan karbohidrat yang tinggi menjadikan Vigna radiate sebagai sumber karbohidrat. Asam folat, protein, thiamin, asam pantotenat, dan mineral (zat besi, kalium, magnesium, fosfor, dan tembaga) dapat berperan dalam pembentukan selsel darah pada sumsum tulang belakang $^{14]}$. Zat besi yang terdapat di dalam Vigna radiata merupakan salah satu unsur penting dalam eritropoiesis (pembentukan sel darah merah). Apabila zat besi dalam bentuk simpanan tercukupi, maka kebutuhan eritropoiesis dalam sumsum tulang akan selalu terpenuhi. Zat besi juga mempunyai fungsi dalam pembentukan anemia yang merupakan bagian dari sel darah merah ${ }^{[8]}$.

\section{SIMPULAN}

Ada hubungan antara konsumsi jus Vigna radiata dan status anemia.

\section{SARAN}

Mahasiswi diharapkan meningkatkan kadar hemoglobin dengan mengonsumsi makanan yang mengandung zat besi, terutama Vigna radiata

\section{DAFTAR PUSTAKA}

1. Arisman. Gizi dalam daur kehidupan: buku ajar ilmu gizi 
cetakan kedua. Jakarta: EGC, 2004;

2. Kemenkes RI. Riset kesehatan dasar 2013 dalam http://www.depkes.go.id/ resources/download/general/Hasil\% 20 Riskesdas\%202013.pdf, diakses pada 20 Februari 2017, 2013. p:256.

3. Varona BM, Maria ETG, dan David AV. Makanan penyembuh ajaib penuntun efektif kepada terapi diet.Bandung: Indonesia Publishing House, 2005. p: 239.

4. Fatmah. Gizi dan kesehatan masyarakat. Jakarta: Rajawali Pers, 2010. p: 141.

5. Irianto K. Gizi seimbang dalam kesehatan reproduksi. Bandung: Penerbit Alfabeta. 2014; p: 93.

6. Wirakusumah ES. Jus buah dan sayuran: 148 resep jus untuk menjaga kesehatan dan kebugaran anda. Jakarta: Penebar Swadaya, 2005. pp: 53,97.

7. Utama TA, Nora L, dan Desi S. Perbandingan zat besi dengan dan tanpa vitamin $\mathrm{C}$ terhadap kadar anemia wanita usia subur. Jurnal Kesehatan Masyarakat Nasional, 2013. 7 (8):344.

8. Kiswari R. Hematologi \& tranfusi. Jakarta: Penerbit Erlangga. 2014. pp:18,94.

9. Suprapto, Tateng S. Bertanam Vigna Radiata. Jakarta: Penebar Swadaya, 1982. p: 2.

10. Sari L. Resep-resep herbal ajaib ala bidan. Yogyakarta: Flash Books, 2013. p: 75. p: 145.

11. Schlenker ED, Sara LR. Williams' Essentials of Nutrition and Diet Therapy Tenth Edition. Amerika: Elsevier Mobsy, 2011. p: 151.

12. Sulistyoningsih H. Gizi untuk kesehatan ibu dan anak. Yogyakarta: Graha. 2011. Ilmu, pp: 56-57.

13. Dieny FF. Permasalahan gizi pada remaja putri. Yogyakarta: Graha Ilmu, 2014. pp: 49, 53.

14. Almatsier S. Prinsip dasar ilmu gizi. Jakarta: Gramedia Pustaka Utama, 2010. pp: 13, 250, 252, 255.

15. Li Y. Iron deficiency and its impact on academic achievement. Journal of Emerald Insight Nutrition \& Food Science, 2009.1 (3): 245.

16. Kurniasari D, Ipik E. Pengaruh Minuman Kacang Hijau terhadap Anemia pada Pendonor Darah di UDD PMI Cabang Kabupaten Pekalongan. Jurnal Ilmiah STIKES Muhammadiyah Pekajangan. 2014.

17. Heltty. Pengaruh Jus Kacang Hijau terhadap Kadar Anemia dan Jumlah Sel Darah dalam Konteks Asuhan Keperawatan Pasien Kanker dengan Kemoterapi di RSUP Fatmawati Jakarta. Tesis. Univesitas Indonesia. 2008.

18. Goyle A, Shyam P. Effect of Supplementation of Micronutrient Fortified Biscuits on Haemoglobin and Serum Iron Levels of Adolescent Girls from Jaipur City, India. Journal of Emerald Insight Nutrition \& Food Science, 2010. 40 (5): 478-481. 